\title{
Kariérne poradenstvo pomáha pri ukončení športovej kariéry
}

\section{Career Consultancy Is Assisting Athletes During Their Career Transition}

\section{Zuzana Sakáčová}

Fakulta telesnej výchovy a športu Univerzity Komenského Bratislava, Slovenská republika

\begin{abstract}
Abstrakt:
Autorka venuje pozornost'otázkam, ktoré sú spojené s teoretickým vymedzením problematiky športovej kariéry, kariérneho poradenstva v športe. Predstavuje Athlete Career Program, ktorý oficiálne podporuje Medzinárodný olympijský výbor (MOV) a jeho cielom je poskytnút pomoc pri rozvoji profesionálnej kariéry športovcov, podnietit integráciu športovcov do pracovného procesu počas, i po skončení sútažnej etapy. Proces ukončenia aktívnej športovej kariéry predovšetkým u profesionálnych športovcov je velmi zložitý a má svoje sociálne, psychologické a právne dimenzie.
\end{abstract}

\begin{abstract}
:
The author of this contribution deals with the questions which are close to theoretical delimitation of the sports career task and career consultancy in sports. The author introduces Athlete Career Program which is officially supported by the IOC. Its aim is focused on the help to develop professional career of the athletes, to stimulate integration of the athletes in working process along with and after competition. The process of concluding an active sports career mainly among professional athletes is rather complicated and has its own social, psychological and legal dimensions.
\end{abstract}

Klúčové slová: profesionálny športovec, kariéra, športová kariéra, dvojitá kariéra športovcov Key words: $\quad$ professional athlete, career, sports career, double sport career

\section{ÚVOD}

Rozhodovanie o budúcej profesii v športe nadobúda nový rozmer, a to v dôsledku závažných spoločenských zmien, ktoré sa uskutočňujú na Slovensku po roku 1989. Diskusia, ako aj teoretické vymedzenie problematiky športovej kariéry, kariérneho poradenstva $\mathrm{v}$ športe, a to tak $\mathrm{u}$ amatérskych, ale aj profesionálnych športovcov sa na Slovensku otvorila len nedávno. Výnimkou na Slovensku je monografia Lešku (2005), v ktorej autor dokumentuje vplyv športu na socializáciu, v jednotlivých etapách športovej kariéry. Treba uviest', že v európskom a svetovom prostredí sa venuje dlhodobá pozornost̉ problematike starostlivosti o športovcov v otázkach kariérneho poradenstva v športe, a to v celom spektre výskumných úloh univerzít, vedeckých športových inštitúcií, ústavov, škôl, športových združení, občianskych združení a iných.

\section{TEORETICKÉ VÝCHODISKÁ}

Každý človek sa v určitej etape svojho života rozhoduje o svojej študijnej, neskôr profesionálnej dráhe a vyberá si z ponúkaných alternatív, a to na základe vlastných kritérií. Pojem kariéra $\mathrm{v}$ širšom kontexte predstavuje spôsob života a sociálne prostredie, v ktorom trávime väčšinu času dňa, a ktoré sa úzko prelínajú s naším osobným životom. Kariéra je celoživotný proces práce na sebe (Rác, 2000), t.j. proces sebatvorby, ktorý umožňuje udržat’ sa konkurencieschopnými na trhu práce. Kariéru označuje Bělohlávek (1994) ako profesionálnu dráhu životom, na ktorej človek získava nové skúsenosti a realizuje svoj osobný potenciál. Zdôrazňuje, že profesionálnu kariéru možno chápat ako sled určitých fáz v profesionálnom živote, $\mathrm{z}$ ktorých každá má svoju špecifickú funkciu, svoju časovú dimenziu a do istej miery určuje aj obsah, charakter fázy nasledujúcej. Kariéra je úspešná realizácia, postup v profesionálnej činnosti, v zamestnaní, v povolaní, vo funkcii a v spoločenskom postavení (Obdržálek, 2004). 
Športová kariéra je dráha športovca v športovej disciplíne, ktorá je dôsledkom jeho optimálneho postupu pri realizácii športového výkonu, resp. výkonnosti. Je sprevádzaná osobným uplatnením a postupom v danej športovej disciplíne, pričom je zodpovedajúco hodnotená jeho spoločenským uplatnením. Ukazuje sa, že v ojedinelých prípadoch športovci zmenia druh športu a tak môžu niektorí športovci mat aj „dve“ športové kariéry. Takéto zmeny môžu byt spôsobené aj tým, že niektorí športovci dosiahnu velké úspechy vo svojom športe a teda aj vo svojej športovej kariére v relatívnom mladom veku a neskôr sa rozhodnú pre iný druh športu. Ďalšie aspekty, ktoré môžu viest' k rozhodnutiu pre vykonávanie iného druhu športu, môžu byt aj finančné problémy a rodinné dôvody, alebo počas vykonávania športu športovci zistia, že ide o nedostatočne lukratívny šport. Častokrát to môže byt̉ striedanie letných a zimných športov, ako je napr. lyžovanie a golf. $\mathrm{V}$ profesionálnom športe je takáto dvojaká kariéra takmer nemožná a to vzhladom na úzku špecializáciu v športe a vykonávanie športovej činnosti počas celého roka.

Kariéra, ktorá nasleduje po ukončení profesionálnej športovej kariéry, je novou časovou dimenziou, novou kariérou. Môže mat' súvislost's predchádzajúcou profesionálnou kariérou, teda športovec sa môže stat trénerom a športovým expertom vo svojom odvetví športu, môže pracovat’ v profesijných organizáciách v oblasti telovýchovy a športu, ako pracovník športových podujatí a športových zariadení, alebo vo funkcii rozhodcu a podobne. Inou možnostou je, že sa počas profesionálnej športovej činnosti pripravuje na úplne inú, novú profesijnú kariéru.

Domnievame sa, že proces naplánovania „správnej športovej kariéry“, ako aj proces „ukončenia športovej kariéry“ je zásadným krokom k dosiahnutiu pocitu spokojnosti a klúčom k dosiahnutiu očakávaných životných štandardov u športovca. Etapy športovej kariéry sa podla Lešku (2005) čiastočne prekrývajú s etapami životného a rodinného cyklu. V mnohom majú svoje odlišnosti a osobitosti, a v podstatnej miere ich môžu modifikovat'. Športovú kariéru rozdeluje na :

1. prípravnú etapu športovej kariéry

2. etapu vyzrievania športovej výkonnosti

3. etapu vrcholovej športovej výkonnosti

4. etapu ukončenia športovej kariéry

Proces ukončenia aktívnej športovej kariéry je vel’mi zložitý a má svoje sociálne, psychologické a právne dimenzie. Sociálne súvislosti sú späté s tým, že športovec stráca svoj sociálny status, sú späté s jeho športovými úspechmi a je nútený zaradit’ sa do bežného života. Psychologické dimenzie sú späté so stratou možnosti svojej sebarealizácie prostredníctvom športu, nedokáže čelit novej konkurencii, stráca obdiv a pozornost' spoločnosti, vytráca sa záujem masmédií, postupne sa na neho zabúda. Právny rozmer ukončenia profesionálnej kariéry je spojený s procesom sociálneho zabezpečenia a to vo forme tzv. „športového dôchodku“. K najdôležitejším subjektom profesionálneho športu patria predovšetkým ich aktéri, profesionálni športovci. V týchto súvislostiach treba uviest', že ani v jednom zákone pre oblast' športu na Slovensku, od roku 1989 (zákon SNR č. 198/1990 Sb. o telesnej kultúre; zákon č. 288/1997 Z. z. o telesnej kultúre a o zmene a doplnení zákona č. 455/1991 Zb. o živnostenskom podnikaní v znení neskorších predpisov ako aj zákon č. 300/2008 Z. z. o organizácii a podpore športu a o zmene a doplnení niektorých zákonov - v súčasnosti má SR dva platné a účinné zákony, ktoré sa dotýkajú právnej úpravy športu) sa nepodarilo vymedzit právne postavenie profesionálneho športovca. Súčasná úprava na Slovensku považuje za profesionálneho športovca fyzickú osobu, ktorá vykonáva svoju profesiu, ako samostatne zárobkovo činná osoba, ktorá však na vykonávanie tejto činnosti nepotrebuje špeciálne povolenie, licenciu zo strany živnostenského úradu. Preto športovci uzatvárajú profesionálne športové zmluvy „Štatutárne zmluvy“, a to občianskoprávne zmluvy, v zmysle $\$ 51$ Občianskeho zákonníka, alebo obchodnoprávne zmluvy v zmysle $\$ 269$ ods. 2 Obchodného zákonníka. Do budúcnosti v aplikačnej praxi možno počítat s osobitnou úpravou pracovnej zmluvy pri vykonávaní športovej činnosti v súlade so Zákonníkom práce, ostatnými všeobecne záväznými právnymi predpismi a s kolektívnou zmluvou, napr. v časti úpravy práv a povinností účastníkov zmluvy, rozvrhovania pracovného času vrátane kontroly jeho dodržiavania, úpravy odmeňovania, zodpovednosti za škodu. $V$ širšom kontexte treba problém faktickej existencie pracovného vztahu pri výkone športovej činnosti vnímat aj ako základ pre plnenie povinností a vznik práv účastníkov zmluvy v iných oblastiach právneho poriadku, bezprostredne v oblasti bezpečnosti a ochra- 
ny zdravia pri práci, v oblasti zdaňovania príjmov, v oblasti zdravotného poistenia a v oblasti sociálneho poistenia (nemocenského, dôchodkového, úrazového, pre prípad nezamestnanosti). Vláda Slovenskej republiky pripravila na rok 2009 návrh legislatívneho zámeru zákona o osobitnom finančnom príspevku športovcom, ktorí sa významnou mierou zaslúžili o športovú reprezentáciu Slovenska (Československa) a to najmä na Olympijských hrách a Majstrovstvách sveta. Predmetom návrhu bola snaha riešit nepriaznivý dopad sociálneho postavenia športovcov po skončení aktívnej činnosti, na sociálne postavenie a pracovné zaradenie športovcov. Malo íst’ o systémové opatrenie a to vyplácaním doživotnej paušálnej mesačnej finančnej čiastky a to v sume trojnásobku životného minima (po predbežných prepočtoch stanovených kritérií by finančný príspevok poberalo $\mathrm{v}$ súčasnej dobe 147 športovcov, s požadovanou sumou cca 946.844 eur [28,524 milióna Sk] za rok. Z kapitoly Ministerstva školstva by finančný príspevok poberalo 125 športovcov). Legislatívny zámer zákona o osobitnom finančnom príspevku športovcom vychádzal zo súčasného stavu sociálneho zabezpečenia športovcov v Slovenskej republike, ktoré je velmi rozdielne. Ako sa uvádza v návrhu, niektorí vykonávajú šport popri zamestnaní, alebo popri štúdiu. Iní sú zamestnaní ako profesionálni športovci v rezortoch školstva, vnútra a obrany. Výška mzdy a sociálneho zabezpečenia v rezorte Ministerstva obrany SR a Ministerstva vnútra SR je rôzna, ale títo športovci po odpracovaní stanoveného obdobia majú nárok na výsluhový dôchodok. V rezorte školstva tento nárok športovcom nevzniká. Návrh legislatívného zámeru zákona o osobitnom finančnom príspevku športovcom, ktorí sa významnou k mierou zaslúžili o športovú reprezentáciu Slovenska (Československa), bol stiahnutý zo septembrového plánu legislatívnych úloh vlády SR na rok 2009 a to na základe zásadných pripomienok štyroch rezortov - Ministerstva financií SR, Ministerstva práce, sociálnych vecí a rodiny SR, Ministerstva obrany SR a Ministerstva vnútra SR. Mad’arsko a Polsko takúto formu sociálneho zabezpečenia pre športovcov už má.

Na Slovensku neexistujú sociologické prieskumy a nemáme $k$ dispozícii štatistické údaje, ktoré by špecifikovali, alebo pomenovávali dôvody, ktoré vedú profesionálnych športovcov k ukončeniu profesionálnej športovej kariéry.

Pokúsime sa načrtnút niektoré $\mathrm{z}$ nich :

1. Ukončenie športovej kariéry $\mathrm{v}$ čase vyzrievania športovej výkonnosti - zranenie, neuspokojivá výkonnost', strata formy, nezvládnutie odlúčenosti od rodičov napr. v internátnej škole, iné záujmy, demotivácia, problémy s trénerom, preceňovanie sa s výkonmi, rozhodnutie rodičov a iné.

2. Ukončenie športovej kariéry $\mathrm{v}$ etape vrcholovej športovej činnosti - zranenie, rodinné problémy, vyhorenie, prechod do iného športu, strata formy a iné.

3. Ukončenie aktívnej športovej kariéry - zranenie, neuzavretie d’alšej profesionálnej zmluvy, vek a iné.

Z uvedeného vyplýva, že športovci v strednom veku musia zmenit svoju profesionálnu kariéru, čo mnohým spôsobuje vel’mi vážne problémy „so začlenením sa do občianskeho života“. Jedným z dôvodov je skutočnost', že počas vrcholovej kariéry majú obmedzený prístup k vzdelaniu, čo im spôsobuje tažkosti pri uplatňovaní sa po skončení aktívnej športovej činnosti. Preto sa mnohí po ohlásení ukončenia športovej kariéry opätovne vracajú k vykonávaniu profesionálnej športovej činnosti. Iní, ak dosiahnu určitý stupeň vzdelania vo svojom športe, sa stanú trénermi, alebo funkcionármi v športových kluboch, zväzoch. Niektorí športovci po ukončení športovej kariéry začínajú v novej profesionálnej kariére tam, kde ich rovesníci začínali pred 20 rokmi. Preto v mnohých športových odvetviach športovci vykonávajú svoju profesiu profesionálneho športovca do veku 40 a viac rokov, teda do veku, o ktorom sa ešte prednedávnom hovorilo už ako o „dôchodkovom veku“ športovca. Ako príklad môžeme uviest' mená slovenských, ale aj svetových športovcov, ako sú : Dominik Hašek - 44 rokov, hokejový brankár, ladový hokej, ČR; Scott Bair - 54 rokov, curling, USA; Elena Kaliská - 37 rokov, vodný slalom, SR; Róbert Pukalovič - 44 rokov, ladový hokej, SR; George Blanda - 48 rokov americký futbal, USA; Nancy Lieberman - 50 rokov, basketbal, USA; Marcel Sakáč sr. - 38 rokov, hokejový brankár, ladový hokej, SR; Dara Toresová - 42 rokov, plávanie, USA; Jeannie Longová - 50 rokov, cyklistika, Francúzsko; Haile Satayin - 49 rokov, maratón, Etiópia; Hiroši Hokecu - 67 rokov, parkúrový jazdec, Japonsko; James Tomkins - 42 rokov, veslár, Austrália; Susan Nattrassová - 58 rokov, stel'ba na asfaltové terče, Kanada a d’alší. 


\section{EURÓPSKA ÚNIA A KARIÉRNE PORADENSTVO V ŠPORTE}

Význam tejto problematiky vyplýva aj z obsahu dokumentu Bielej knihy o športe (2007) a taktiež z návrhov Európskej únie, ktorá odporúča členským štátom:

- zabezpečit reintegráciu profesionálnych športovcov do trhu práce na konci ich športovej kariéry,

- zohladňovat potrebu poskytnutia prípravy na „dvojitú “ kariéru, športovú a akademickú, u mladých športovcov od začiatku, s cielom umožnit profesionálnym športovcom opätovné začlenenie na trh práce po ukončení ich kariéry, s osobitným dôrazom na vzdelávanie najmladších. Preto je nevyhnutný prísnejší dohlad a pravidelné kontroly prípravy, aby sa zaručila kvalita a aby sa zriad’ovali vysokokvalitné miestne vzdelávacie centrá, ktoré budú garantom ich morálnych, vzdelávacích a profesionálnych záujmov; považuje za neprijatel’né, aby profesionálni športovci mali menej práv ako iní zmluvní zamestnanci, a považuje preto za potrebné, aby profesionálni športovci mohli využívat rovnako široký a transparentný rozsah práv ako iní zamestnanci vrátane práva na uzatvorenie, alebo zamietnutie kolektívnych dohôd a na členstvo v odborových zväzoch a právo obrátit sa na všeobecné súdy (v stanovisku „Výboru pre zamestnanost’ a sociálne veci“, pre „Výbor pre kultúru a vzdelávanie“, k Bielej knihe o športe z 29.2.2008 sa odporúča, aby gestorský výbor zaradil do návrhu uznesenia pre Komisiu, uznat spoločenský a vzdelávací rozmer športu, vyzvat členské štáty, aby prijali všetky nevyhnutné opatrenia, ktoré zabezpečia, že tí športovci, ktorí o to majú záujem, budú môct’ po skončení svojej športovej kariéry absolvovat’ odborné vzdelávanie a prípravu s cielom odovzdávat svoje skúsenosti a poznatky mladým športovcom a športovkyniam. Je nevyhnutné, aby sa mladí športovci a športovkyne od začiatku vzdelávali tak $\mathrm{v}$ oblasti športu, ako aj v akademických predmetoch, pretože sa tým zabezpečí opätovný návrat profesionálnych športovcov na trh práce po skončení ich športovej kariéry. Komisia v týchto súvislostiach odštartovala štúdiu o príprave mladých športovcov a športovkýň v Európe, ktorej výsledky by mohli poskytnút informácie pre už spomenuté politické opatrenia a programy). Biela kniha o športe uvádza, že sociálny dialóg na európskej úrovni môže zmiernit obavy zamestnávatelov a športovcov a môže zahrňovat aj preskúmanie dohôd týkajúcich sa vztahov medzi nimi a pracovných podmienok v tomto odvetí.

Aj Európska Charta o športe v čl. 8 „Podporovanie vrcholového a profesionálneho športu“ uvádza, že: 1 . Metódy poskytovania primeranej priamej či nepriamej podpory športovcom a športovkyniam, ktorí prejavia výnimočné športové kvality, sa rozpracúvajú v spolupráci s príslušnými športovými organizáciami, aby mohli športovci naplno rozvinút svoje športové a ludské schopnosti, pri plnom rešpektovaní ich osobnosti, telesnej a morálnej integrity. Takáto podpora je zároveň zameraná na vyhladávanie talentov, ich vyvážené vzdelávanie v športových školách, ako aj na bezproblémovú integráciu do spoločnosti vytváraním možností pracovného uplatnenia počas vrcholovej športovej kariéry a po jej skončení. 2. Organizáciu a riadenie profesionálneho športu majú v kompetencii príslušné odborné orgány. Profesionálni športovci majú mat̉ zabezpečené primerané sociálne postavenie a ochranu, ako aj morálne záruky proti všetkým formám zneužitia.

Účastníci XIII. olympijského kongresu v Kodani v októbri 2009 schválili 66 odporúčaní, návrhov a to v piatich tematických oblastiach (Téma 1.: Športovci - Vztah medzi športovcami, klubmi, federáciami a NOV; 1.1 Ochrana zdravia pri tréningu a sútažiach; 1.2 Spoločenský a profesionálny život športovcov počas a po skončení vrcholového sútaženia; Téma 2: Olympijské hry; 2.1 Ako zabezpečit, aby olympijské hry zostali prvoradou udalostou?; 2.2 Olympijské hodnoty; 2.3 Univerzálnost’ a rozvojové krajiny; Téma 3: Štruktúra olympijského hnutia; 3.1 Autonómnost' olympijského hnutia; 3.2 Správne riadenie a etika; 3.3 Vztah medzi olympijským hnutím a zainteresovanými stranami ; Téma 4: Olympizmus a mládež; 4.1 Vývoj smerom k aktívnej spoločnosti; 4.2 Je sútažný šport stále prítažlivý?; 4.3 Športové udalosti pre mládež; Téma 5: Digitálna revolúcia; 5.1 Nový manažment športových práv; 5.2 Ako zvýšit počet športových divákov ?; 5.3 Komunikácia so zainteresovanými stranami v digitálnom veku). V prvej oblasti „Športovci“ sa odporúča, aby sa všetky riadiace orgány v rámci olympijského hnutia prihlásili k významu spájania športovania a vzdelávania a prioritou by pre ne malo byt vyvinutie programov zameraných na rozvoj mimo športových zručností športovca, tak počas jeho sútažnej kariéry, ako aj po jej skončení. 
Dôležitou skutočnostou v živote športovcov je aj otázka sociálneho zabezpečenia po skončení športovej kariéry a v Slovenskej republike sa jej doteraz nevenovala náležitá pozornost'. Preto bol vypracovaný program profesionálneho zabezpečenia športovcov po ukončení aktívnej športovej kariéry z verejných zdrojov. Slovenský Olympijský výbor nadviazal spoluprácu s profesionálnou agentúrou ADECCO a za jej spolupráce pripravil tzv. program „Athlete Carreer Program“. Tento program oficiálne podporuje Medzinárodný olympijský výbor (MOV) a jeho cielom je poskytnút pomoc pri rozvoji profesionálnej kariéry športovcov, podnietit integráciu športovcov do pracovného procesu počas i po skončení sútažnej etapy. Jeho cielom je taktiež podnietit u zamestnávatelov záujem spolupracovat s lud’mi disponujúcimi jedinečnými vlastnostami a kvalitami. V súčasnosti program „Kariérne zabezpečenie športovca“ realizuje Národné športové centrum. Je zameraný na dve hlavné oblasti:

a) profesionálny rozvoj športovca za účelom podpory a skvalitnenia jeho športovej kariéry $v$ činnostiach, ktoré nesúvisia priamo s tréningovým procesom. Toto skvalitnenie je možné dosiahnut zlepšením komunikácie športovca s trénerom, kolegami, podporným tímom, funkcionármi, ale aj médiami;

b) osobnostný rozvoj športovca, ktorý je zameraný na výber a podporu kariéry športovca po ukončení aktívnej športovej činnosti, ked' samotná príprava (kariérne zabezpečenie športovca) prebieha ešte počas jeho aktívneho športovania.

Program môžeme chápat ako praktické rady pre hráčov (trénerov), aby získali väčšiu dôveru v seba a boli úspešní po skončení športovej kariéry. Zameriava sa na profesionálny rozvoj športovca a to v nasledujúcich oblastiach :

1. pozitívne športové prostredie - budovanie tímu, pozitívne-asertívne správanie, riešenie konfliktov; 2. výživa a poruchy príjmu potravy, doping, podporné prostriedky v športe; 3 . komunikácia s médiami - osobnostné práva na ochranu osobnosti; 4. vystupovanie na verejnosti; 5 . osobný marketing - prezentovanie sa firmám, potenciálnym sponzorom. Osobnostný rozvoj športovca formou konzultácií - poradenských služieb a interaktívnych seminárov. Športovci majú možnost’ vzdelávat’ sa v nasledovných oblastiach: 1. plánovanie kariéry - plánovanie času, finančné plánovanie, osobný rozpočet; 2 . výber školy a štúdium - sledovanie priebehu štúdia, formy štipendií na Slovensku, štipendiá na zahraničných univerzitách, žiadosti a potrebné jazykové skúšky na prijatie na zahraničnú univerzitu; 3. príprava životopisu a sprievodného listu - oficiálne listy - dakovné, žiadosti napr. o finančnú podporu na sústredenia, sútaže, pozvánky; 4 . vhodné zamestnanie a jeho vyhladávanie, 5. plynulý prechod z aktívnej činnosti do zamestnania (v súčasnosti je program určený pre vrcholových športovcov, ktorí spĺňajú nasledujúce podmienky: vek 17 rokov a starší, reprezentant SR v kategórii junior, resp. senior, alebo na odporučenie príslušného športového zväzu).

Významnú pomoc pre profesionálnych športovcov zohrávajú športové agentúry, ktoré sa vytvárajú $\mathrm{v}$ súčasnosti aj na Slovensku, a ktorých činnost’ je zameraná na: 1. manažérsku a poradenskú činnosṫ - zastupovanie hráčov, uzatváranie a predlžovanie profesionálnych zmlúv, realizáciu prestupov v rámci SR a v zahraničí, plánovanie hráčskej kariéry, sprostredkovanie odbornej lekárskej starostlivosti; 2. scouting - vyhladávanie talentov, spolupráca zo zahraničnými skautmi pri realizácii medzinárodných prestupov; 3. právne služby - sprostredkovanie právnych služieb v občianskoprávnych záležitostiach, sprostredkovanie právnych služieb v trestnoprávnych záležitostiach, sprostredkovanie právnych služieb v obchodnoprávnych záležitostiach; 4 . finančné poradenstvo - vedenie účtovníctva, daňové poradenstvo; 5 . reklama a marketing - zaistovanie sponzoringu pre klientov spoločnosti, sprostredkovanie vystupovania klientov v reklame, zaistovanie účasti klientov na akciách spoločenského a športového charakteru; 6 . organizovanie stáží pre hráčov aj trénerov v zahraničných kluboch; 7. PR (Public relations - práca s verejnostou, styk s verejnostou, vztahy k verejnosti) a Média: tlačové konferencie a podobne.

Viac ako polovicu svojho aktívneho pracovného života vykonávajú profesionálni športovci profesionálnu činnost' (vek od 15 rokov do...). Počas svojho „športového profesionálneho života“ sú v strede pozornosti fanúšikov, sponzorov, mecenášov, trénerov, celej spoločnosti, štátov. Ich životy, ich profesia, ich práca je pod drobnohladom, často sú pod tlakom verejnej kritiky, médií. Hodnotí sa ich pracovný výkon, správanie, rodinný život, spoločenský život, píše sa o nich, ked porušia športové, právne, ale aj spo- 
ločenské normy. Sú predmetom záujmu, ked’ ukončia profesionálnu kariéru. Mnohí profesionálni športovci vo svojich spomienkach opisujú svoj život po ukončení profesionálnej športovej kariéry. Uvádzajú, že odíst' z tejto profesie je vel'mi zložité. U mnohých sa začali prejavovat psychické, emocionálne a fyzické problémy. Mnohí užívajú drogy, stanú sa z nich alkoholici, prežívajú vážne rodinné tragédie, rozvádzajú sa a mnohí sa pokúšajú spáchat’ samovraždu. Profesionálnemu športovcovi sa po skončení športovej kariéry môže rozpadnút motivačná štruktúra osobnosti. Život ukazuje množstvo príkladov, ked športovci počas svojej kariéry i po jej skončení vlastným neuváženým konaním prišli o značné množstvá peňazí, čo je samozrejme tažko nahraditel’ná škoda, a rozpadli sa im klúčové životné vztahy, čo je už nenahraditelná strata (Gregor, 2006).

Ako povedal predseda Slovenského olympijského výboru František Chmelár, bohatých športovcov je vo svete, ale aj na Slovensku vel’mi málo. Len málo je takých, ktorí si dokážu počas svojej športovej kariéry zarobit tolkko, aby mohli z toho žit' celý život. Určite to nie sú atléti, zápasníci, vodní slalomári alebo biatlonisti. Preto myšlienka dôchodkov pre vynikajúcich športovcov je v športovom hnutí stále aktuálna. Mnohí z nich po skončení športovej kariéry sa len velmi tažko začleňujú do civilného života a mnohí aj na Slovensku žijú na úrovni chudoby. Vynikajúci československý futbalista Antonín Panenka, ktorý je predsedom Nadácie futbalových internacionálov v Českej republike, na margo diskusie o „športovom dôchodku“ v Česku povedal: „Naši fotbaloví internacionáli žijí bohužel často v ubohých podmínkách a na zašlou slávu už jen smutně vzpomínají. Jejich kluby na ně povětšinou zapomínají, takže kolikrát jsou dojati k slzám, že si na ně někdo vzpomněl. Posláním Nadace fotbalových internacionálů (založena $v$ roce 1993) bylo a je pomáhat bývalým reprezentantưm, kteři ve své době dělali našemu fotbalu dobré jméno, a dnes žijí často pod hranicíživotní úrovně. Za patnáct let činnosti jsme takto potřebným rozdali 20 miliónu korun. Těm nejpotřebnějším platíme třeba léčbu, léky, zajištujeme operace. Svátovi Pluskalovi jsme platili měsičně 20 tisíc za pobyt v léčebném zařizení. Ted’ třeba pomáháme Lád’ovi Novákovi tím, že mu kupujeme léky. Když jeden z nás neměl práci, ostatní nasadili v̌̌echny páky, aby byl zase brzy zaměstnaný. Pocit, že je člověk bezcenný a bez zájmu okolí, je totiž hrozný." (Panenka, 2008).

Domnievame sa, že vel'kú úlohu v tomto projekte môže mat’ aj Fakulta telesnej výchovy a športu v Bratislave, ktorá vytvára podmienky pre aktívnych športovcov. Sú to napríklad vodní slalomári Ladislav a Peter Škantárovci, strelec Ladislav Gönci, ako aj další vynikajúci slovenskí futbalisti/tky, hokejisti/tky, volejbalisti/tky, basketbalisti/tky, karatisti/tky, zápasníci, vodáci/čky, gymnasti/tky, ale aj športovci z iných športových odvetví, ktorí dosiahli na Fakulte telesnej výchovy a športu v Bratislave najvyššie univerzitné vzdelanie z oblasti vied o športe. Mnohí získali trénerské vzdelanie, ako napríklad olympijskí vítazi bratia Pavol a Peter Hochschornerovci a rad d’alších. Mnohí pokračujú na Fakulte telesnej výchovy v Bratislave v doktorandskom štúdiu. Práve títo športovci môžu byt’ v budúcnosti vynikajúcimi trénermi a na základe dosiahnutého vzdelania môžu odovzdávat bohaté skúsenosti zo športovej činnosti mladej generácii športovcov na Slovensku.

\section{ZÁVERY PRE ŠPORTOVÚ PRAX}

- realizovat, uplatňovat’ závery Bielej knihy o športe (2007) v oblasti kariérneho poradenstva v športe,

- umožnit športovcom prípravu na „dvojitú “ kariéru, športovú a akademickú,

- dosiahnut vzdelanie v rámci ISCED 3 (vyššie sekundárne vzdelávanie),

- možnost́ získat adekvátne trénerské vzdelanie,

- legislatívne ukotvit sociálne zabezpečenie športovcov (športový dôchodok) pre olympionikov, majstrov sveta.

Možno odôvodnene predpokladat', že zmeny spoločenských i právnych vztahov so vstupom Slovenska do Európskej únie priniesli výrazné zmeny aj v oblasti vzţahov športu a práva. Pretože máme aj v tejto oblasti vela neujasnených teoretických, metodických, metodologických, praktických, ale aj legislatívnych a d’alších otázok, je potrebné tejto oblasti venovat náležitú pozornost'. 


\section{Literatúra}

BAUMAN, Z. Kariéra. Sociologické črty. Praha : Mladá fronta, 1967.

BĚLOHLÁVEK, F. Osobní kariéra. Praha : Grada, 1994. ISBN 80-7169-083-X.

Biela kniha o športe. Luxemburg : Úrad pre vydávanie úradných publikácií Európskych spoločenstiev, 2007. ISBN 978-92-79-06563-7.

ČERNÁK, V., LINHART, J. Sociologie sportu. Praha : Olympia,1986.

Európska Charta o športe. Bratislava : Informačná kancelária Rady Európy, 2004. ISBN 80-89141-06-4.

DOVALIL, J. a kol. Malá encyklopedie sportovního tréninku. Praha : Olympia,1980.

Európska konferencia „Výchova prostredníctvom športu“ [online] 2008 [cit.2009-05-22]. Dostupné na www: http://www.education-through-sport.eu/sk/.

GREGOR, T. Potenciálne rizikové skupiny osôb pre športovcov [elektronický optický disk (CD ROM)]. In Sport a kvalita života 2006. Sport and quality of life 2006. Brno : Masarykova univerzita, 2006. - elektronický optický disk (CD ROM).

HAMERNÍK, P. Sportovní právo s mezinárodním prvkem. Praha : Auditorium, 2007. ISBN 978-80-903786-1-2.

CHARVÁT, M. Sociální aspekty sportovních aktivit. - 1. vyd. Brno : Paido, 2002.ISBN 80-7315-029-8.

JEDLIČKA, J. Vrcholový sport a regulace v EU. [online] 2006 [cit.2009-08-15]. Dostupné na www: http:// www.csas.cz/banka/content/inet/internet/cs/Sport_EU.pdf.

KOLEKTIV AUTORŮ. Otázky sportovního práva. Praha : Ústav státu a práva AV ČR, 2008. ISBN 978-904024-1-6.

KRÁLIK, M. Právo ve sportu. Praha : C.H.Beck, 2001. ISBN 80-7179-532-1.

LEŠKA, D. Sociológia športu. Bratislava : ICM AGENCY, 2005. s. 103-140. ISBN 80-969268-4-5.

LEŠKA. D. Šport ako faktor socializácie osobnosti. In Acta Facultatis Educationis physicae Universitatis Comenianae, 45. Bratislava : Univerzita Komenského, 2004. s. 115-125. ISBN 80-223-2014-5.

MÍKA, V. T. Základy manažmentu. Virtuálne skriptá. [online] 2006 [cit.2009-07-15]. Dostupné na www: http://fsi.uniza.sk/kkm/publikacie/ma/ma_00.pdf.

Návrh zmluvy zakladajúcej Ústavu pre Európu. Luxemburg : UPVUPES, 2005. ISBN 92-824-3115-0 EU.

OBDRŽÁLEK, Z. a kol. Organizácia a manažment školstva. Terminologický a výkladový slovník. Bratislava : SPN. s. 137, 2004. ISBN80-10-00022-1.

OLEJÁR, M. Športová kariéra. [online] 2007 [cit.2009-08-22.]. Dostupné na www : http://www.ys.sk/ heslo/makrocyklus.

PANENKA, A. Muž, který rád rozdává štěstí. [online] 2008 [cit.2010-01-22]. Dostupné na www: http:// www.eurofirma.cz/slideshow/archiv_soubor1124.pdf.

PERÚTKA, J. a kol. Malá encyklopédia telesnej výchovy a športu. Bratislava : Obzor. 1980.

PICHŇA, J. Sociológia práce. Bratislava : Práca, 1978.

Pripomienky k legislatívnemu zámeru zákona o športe. [online] 2007 [cit.2009-05-15]. Dostupné na: www:http://www.klub500.sk/klub500/home.nsf/page/6C68ADED6747D03DC12572910026C7BA?Ope nDocument.

Plánovanie kariéry. [online] 2009 [cit.2009-06-24]. Dostupné na www : http://jobs.sk.hudson.com/node. asp?kwd=kariera-planovanie.

RÁC, I. Kvalifikácia, vzdelanie a sloboda profesnej kariéry. [online] 2000 [cit.2009-06-24]. Dostupné na www : http://web.tuke.sk/anta/kariera.htm.

SAKÁČOVÁ, Z. Právne aspekty integrácie slovenského športu do Európskej únie. In ACTA FACULTATIS EDUCATIONIS PHYSICAE UNIVERSITATIS COMENIANAE, Publicatio XLII, Bratislava : Univerzita Komenského, 2001. s.129-137. ISBN 80-223-1694-6.

SAKÁČOVÁ, Z. Limits of athlete's claim enforcement / Social dimensions of sport and recreation development in Central European countries, Bratislava : Národné športové centrum a Fakulta telesnej výchovy a športu UK, 2007 s. 137-146. ISBN978- 969-702-0-9.

SAKÁČOVÁ, Z. Uplatňovanie práv detí v športe a ich ochrana v pracovnom práve. Sport a kvalita života 2008. Sport and quality of life 2008, Brno : Masarykova univerzita, 2008, s. 1-10. ISBN 978-80-210 4716-7. 
SAKÁČOVÁ, Z. Aplikácia medicinskeho práva na šport. Bratislava: FIDAT, 2009. ISBN 978-80-969504-4-7. SAKÁČOVÁ, Z. Kariérne poradenstvo v športe. In: Amaterizmus a profesionalizmus v športe. Bratislava : Mačura - PEEM. 2009, s.32-42. ISBN 978-80-8113-017-5.

SEKOT, A. Sport a společnost. Brno : Paido, 2003. ISBN 80-7315-047-6.

SLUKA, T. Profesionální sportovec (právní a ekonomické aspekty). Havlíček Brain Team, 2007. ISBN 80-903609-5-5.

Stanovisko Výboru pre zamestnanost' a sociálne veci pre Výbor pre kultúru a vzdelávanie k Bielej knihe o športe (2007/2261(INI)) [online] 2007 [cit.2009-06-24]. Dostupné na www: http://www.europarl.europa.eu/meetdocs/2004_2009/documents/ad/711/711033/711033sk.pd.

Závery a odporúčania XIII. olympijského kongresu v Kodani. [online] 2009 [cit.2009-06-24]. Dostupné na www: http://www.olympic.sk/olympijsky-kongres.html.

Zákony:

Ústava SR - zákon č. 460/1992 Zb. v znení neskorších predpisov

Zákon NR SR č. 288/1997 Z.z. o telesnej kultúre a o zmene a doplnení zákona č. 455/1991 Zb. o živnostenskom podnikaní (živnostenský zákon) v znení neskorších predpisov

Zákon NR SR 213/1997 Z.z. o neziskových organizáciách poskytujúcich všeobecne prospešné služby $\mathrm{v}$ znení neskorších predpisov

Zákon č. 300/2008 Z. z. o organizácii a podpore športu a o zmene a doplnení niektorých zákonov

Zákon NR SR č. 479/2008 Z. z. o organizovaní verejných telovýchovných podujatí, športových podujatí a turistických podujatí a o zmene a doplnení niektorých zákonov

Vyhláška MŠ SR 542 z 25. novembra 2008 o postupe pri vykonávaní dopingovej kontroly a pri nakladaní s odobratými biologickými vzorkami športovca

Vyhláška MŠ SR 444 z 27. októbra 2008 o akreditačnej komisii pre oblast telesnej kultúry a o Jednotnom vzdelávacom systéme odborníkov v športe Slovenskej republiky

Zákon č. 29/2009 Z. z. Úplné znenie zákona č. 288/1997 Z. z. o telesnej kultúre a o zmene a doplnení zákona č. 455/1991 Zb. o živnostenskom podnikaní (živnostenský zákon) v znení neskorších predpisov. Zákon č. 328/2002 Z. z. o sociálnom zabezpečení policajtov a vojakov a o zmene a doplnení niektorých zákonov a Zákon č. 433/2008 Z. z. o zvýšení výsluhových dôchodkov zo sociálneho zabezpečenia policajtov a vojakov v roku 2008 